AUTHOR:

Jonathan D. Jansen

\section{AFFILIATION:}

${ }^{1}$ Distinguished Professor, Faculty of Education, Stellenbosch

University, Stellenbosch,

South Africa

\section{CORRESPONDENCE TO:}

Jonathan Jansen

\section{EMAIL:}

jonathanjansen@sun.ac.za

\section{KEYWORDS:}

psychology; autobiography; ideas; apartheid; South Africa

\section{HOW TO CITE:}

Jansen JD. On the power of restraint in the writing of lives: Humanities Book Award 2018. S Afr J Sci. 2018;114(11/12), Art. \#a0295, 2 pages. https://dx.doi. org/10.17159/sajs.2018/a0295

\section{PUBLISHED:}

27 November 2018
(C) 2018. The Author(s). Published under a Creative Commons Attribution Licence.

\title{
On the power of restraint in the writing of lives: Humanities Book Award 2018
}

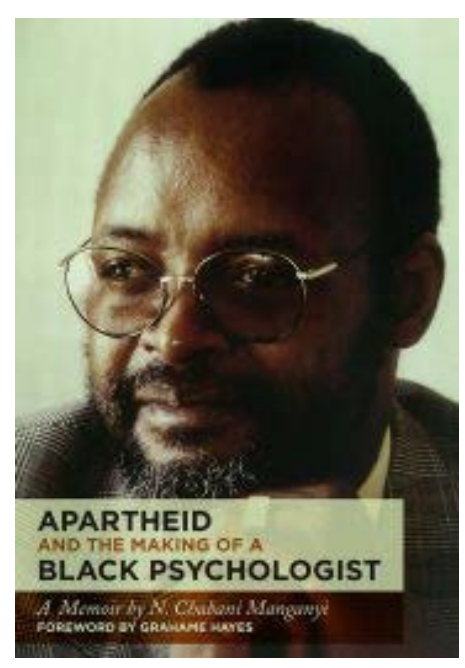

It is a wisdom attributed to the Greek historian Thucydides, that 'Of all manifestations of power, restraint impresses men most'. To read Chabani Manganyi's Apartheid and the Making of a Black Psychologist is to be awed by the power of restraint in the hands of a capable author and a compelling thinker. Restraint, in this context, is not synonymous with 'not telling' or 'holding back' on writing about a troublesome event. In the hands of a highly skilled writer, restraint is a way of communicating where the very art of control over the writing enables the telling to explode off the pages of the book.

Since the end of apartheid there has been a veritable industry of autobiographies reminding readers exactly how bad the past was or how its terrible legacy hovers in the present. Everyone has a story to tell, from exiles to 'inziles', from military officers of the white regime to soldiers of the liberation movements, from heroes of the struggle to memoirs of the 'born free'. In all these books the prose is unsubtle, sometimes crude, and often angry. This kind of biographical writing is so common that Manganyi's book surprises with its insight, subtlety and restraint.

What made this scholarly masterpiece, published by Wits University Press in 2016, the unanimous choice for the 2018 ASSAf Humanities Book Award - among 38 competitors - is its uniqueness in another respect. This contribution is, in essence, a history of ideas told through the life story of a black psychologist since the 1940s. Skilfully, the account of Manganyi's life is intertwined with his evolving ideas about the human condition and the growth of ideas in his specialist field of psychology - all of which is done against the backdrop of the advent and unfolding of apartheid from 1948 onwards.

It is painful reading the vivid account of the impact of the migrant labour system on his father and the family. Without rancour, Manganyi shows exactly how migrant work sought to sustain fragile domestic economies even as it separated families and stripped self-respecting African men of dignity, reducing them to 'an unmistakeable sense of shame, silent anger and regret' (p. 11).

Manganyi goes on to account for his life in a mission boarding school called Lemana in today's Limpopo Province and his passage through university as a student and later as a professor and head of psychology at the Umtata Campus of the University of Fort Hare. In briefly referencing the story of these two institutions - Lemana and Umtata - Manganyi offers a first-hand account of how apartheid transformed powerful black institutions into intellectual wastelands. He remembers how an 'intellectual bounty of excellent teachers' (p. 12) at school would be cancelled out by Bantu Education and how a campus with lecturers of 'outstanding academic promise' (p. 56) would be flattened by the new homeland system that brought into existence the University of Transkei. Manganyi is correct that these transformations of institutions by apartheid in the 1950s have yet to be more fully accounted for in scholarly histories of education, especially in the case of Fort Hare's Umtata Campus that stood on the brink of building from the ground up a place of academic excellence.

It is, however, in his search for a job that the systematic racism of organisations becomes evident - from his short stay as 'Employee Relations Officer' at Ellerines furniture company to the denial of his request for internship training in clinical psychology settings in the only place that offered such opportunity, white hospitals. Tongue-in-cheek, Manganyi quips that 'the most difficult hurdle, and one that could not be easily overcome, was the colour of my skin' (p. 26). So he ends up at Baragwanath Hospital - as a clinical psychologist in training in a neurosurgery department - and is housed in the black doctors' quarters. Time after time his career was sabotaged by the race laws of apartheid and the bigotry of businesses (Ellerines pushed him out because he pointed to racism as the reason for the high turnover of black staff) and institutions such as Wits which could not get itself to appoint this brilliant black scholar as anything more than a 'Visiting Professor' - a shame the Johannesburg university has never corrected.

This is where the foundation of Manganyi's intellectual orientation is revealed. He is no victim of the apartheid's suffocating 'laws and practices that followed me relentlessly' ( $p$. xiv). Manganyi is equipped with an unusual curiosity about life, such as that expressed in his seminal publication Being-black-in-the-world. Time after time he turns frustration into a quest for deep understanding. A vicious caning for absenteeism from school is a chance for reflection: 'I still wonder what would have happened if the principal had spared the cane' (p. 3). The substandard black doctors' quarters at Baragwanath offered insight into 'the social and intellectual culture of a racially segregated teaching hospital' (p. 27). Manganyi was haunted by the horrific necklacing of the suspected police informer, Maki Skosana, which launched him into a funded study on political violence. And as an expert witness defending activists from the death penalty, he was intrigued by the biographies of those accused of political murders and brought these richly drawn contexts to the attention of the courts for mitigation of sentence.

At this point, a personal but related note. It was Professor Manganyi who advised the then Rector of the University of Pretoria to recruit me as Dean to this formidable Afrikaans institution. Each Dean reported to a Vice-Rector 
and I was lucky to at one stage report to Manganyi. Rather than talk academic business and administration, our weekly sessions turned out to be two-man seminars on complex questions of campus and country. One day I came for my usual consultation and complained bitterly about race, hierarchy and bureaucracy at the university. My mentor listened for a while and then, in his typically calm and reserved manner, said something that changed the direction of my own scholarship. 'JJ' he mused, 'your problem is that you get angry before you think. Try and make sense of what is going on in this place.' That was the moment in which the idea for my book, Knowledge in the Blood: Transforming Race and the Apartheid Past, was born. He had taught me an invaluable lesson: try to understand deeply that which frustrates you, for then, and then only, can you change it.

A demeanour of restraint did not mean that Manganyi was not at various point(s) angry, frustrated and even embittered by the traumatic experiences of his life. But he expressed it through his scholarship, as in the semi-fictional work Mashangu's Reverie, a work of self-analysis which 'started to rid myself of disturbing impulses' (p. 47). It was when he was out of the country, on a scholarship to Yale University, that Manganyi found himself free to be angry, to unburden himself through writing and to contemplate the possibility of life in exile - a contemplation which would complete a trilogy of biographies on the lives of exiled South Africans.

The golden thread binding together the various moments in Manganyi's compelling life story is ideas. The mission school gave access to 'the world of knowledge' (p. 14) and 'discoveries of science' (p. 13) despite its colonial bent. The University of the North offered access to the disciplines by knowledgeable (white) lecturers and an assistantship opportunity in educational psychology despite the ideological distortions of apartheid education. The honours degree in psychology at Unisa provided a 'most stimulating' (p. 19) exposure to studies in the philosophy of science. Then followed a master's degree drawing on Maslow's theory of human needs among factory workers and furniture salesmen using statistical methods; there was much frustration with the unresponsive white supervisor but 'I did not twiddle my thumbs in confusion and self-pity' (p. 24), recalls Manganyi who soon qualified for doctoral studies.

Despite these solid foundations in clinical psychology, discrimination meant pursuing ideas on his own and through opportunities in non- ideal places such as the neurology department at Baragwanath and without specialist supervision in psychiatry. Even as an expert witness in apartheid courts, he was practising forensic psychology when the field was in its infancy. 'But' says Manganyi, 'I kept my eyes and ears open' (p. 29) and 'I read myself into important but unfamiliar knowledge domains' (p. 30). In other words, his formal academic and clinical training came through a combination of structured teaching and professional neglect out of which he crafted, through reading and observation, the knowledge necessary for success as a psychologist - such as his forays into the study of hysteria. It was the opportunity to study at Yale as a postdoctoral fellow that enabled Manganyi to escape 'the minimalist hit-and-miss experience I had to create for myself at Baragwanath' (p. 40). Here he would gain thorough knowledge in a range of clinical psychology skills such as psychoanalytic psychotherapy. Returning home, Manganyi's ideas returned him to a life-long interest in biography, capturing the lives of Eskia Mphalele, Dumile Feni and Gerard Sekoto in powerful accounts of the exiled condition.

Strikingly, Manganyi has been able to maintain an active research and publication schedule throughout his career in academic leadership in psychology, governmental leadership as Director General for Education, university leadership as Vice Chancellor and executive leadership of a major private sector funded organisation. A man of ideas, he never abandons his intellectual pursuits, always asking hard questions about the human condition.

Chabani Manganyi is among the last of a special class of South African intellectuals who treasured ideas above the pursuit of wealth, status or petty politics. When told at the end of his stint as Director General for Education that he would be 'redeployed', you could inflict on this cultured man no greater insult; he declined the offer. When he engaged academic staff at the University of the North on critical matters at the university, his heart sunk as he took in the low level of academic discourse and ambition, prompting the Vice Chancellor to start planning his exit. In the world of Manganyi, ideas still mattered.

What this award-winning book accomplishes is to turn the two major intellectual preoccupations of Manganyi's professional career psychology and biography - into a powerful work of psychobiography applied to his own life. In this sense, his work and his life have come full circle and, in the process, he teaches generations of South Africans how to be human in a broken world. 